\title{
Dividend Pricing Models and REITs
}

\author{
Jarl G. Kallberg, New York University \\ Crocker H. Liu, New York University \\ Anand Srinivasan, University of Georgia
}

\begin{abstract}
Dividend pricing/present value models relate current stock prices to expectations of future dividends. In this study we apply the West and Campbell-Shiller tests of the dividend pricing relation to an index of real estate investment trusts (REITS). REITs provide a unique test of these models since, during our study period, REITs were mandated to pay out at least $95 \%$ of taxable income as dividends. While our results complement previous research which finds that the dividend pricing model cannot be rejected if share repurchase is included as part of dividends, our data contain a much less significant amount of share repurchase, so that our approach to the issue of the viability of dividend pricing models offers an alternative insight. Our research suggests that, for our REIT population, dividend pricing models cannot be rejected.
\end{abstract}

Empirical research has found that dividend pricing models, or present value models, when tested on market indexes, are poor predictors of true prices. The literature ${ }^{1}$ initially cited this lack of fit as evidence of "excess volatility," the notion that prices move too much to be explained by changes in fundamental factors such as dividends and discount rates. More recently, however, this research has been recast as a rejection of the pricing model, in particular, the failure of the assumption of a constant dividend rate to hold. The viability of dividend pricing models has important implications for market efficiency, market microstructure and asset pricing.

The majority of the research uses the following simple present value relation, which forms the basis of the valuation of financial and real assets:

$P_{t}^{*}=\sum_{i=1}^{\infty} \beta^{i} d_{t+1}$, where $P_{t}^{*}$ is the "ex post rational" price at time $\mathrm{t}, \beta^{i}$ is the reciprocal of the discount rate for cash flows $i$

\footnotetext{
${ }^{1}$ See Shiller (1979, 1981), LeRoy and Poner (1981), Campbell and Shiller (1987, 1988a. 1988b) and West (1988a).
} 
periods in the future and $\mathrm{d}_{\mathrm{i}+\mathrm{t}}$ is the payoff $i$ periods from time $t$. In these models, payoff is usually synonymous with future dividend payment, although a few authors have taken a broader definition. The intuition of Equation $\{l)$ is that in an efficient market a firm's stock price is the discounted value of its future dividend stream.

This article assesses the validity of dividend pricing/present value models by focusing on real estate investment trusts \{REITs). While the characteristics of REIT dividend payments are clarified below, it is important to emphasize a fundamental distinction between REITs and regular corporations. REITs are unique in that they typically pay out almost all of their funds from operations as dividends. ${ }^{2}$ This dividend payout regime sterns from their legal obligation to pay out at least $90 \%$ of their taxable income as dividends; this figure was $95 \%$ prior to 2000 . This removes much (hut not all) of the firm's discretion over its dividend payout and should make the dividend pricing/present value relation more plausible than for typical equities or equity indexes. While West (1988a). Campbell and Shiller $\{1987,1988$, 1988b) and others reject models based on Equation (1), Ackert and Smith \{1993), by broadening the definition of dividends to include share repurchases and other distributions, cannot reject the dividend pricing model.

Our study is much in the spirit of Ackert and Smith's (1993) work. However, in our data set share repurchases are not nearly as significant a factor. Rather, the driving force is the difference in the manner in which REITs versus typical equities determine dividend payouts. Like Ackert and Smith, we find support for dividend pricing models. Knowing that these models fit REITs well provides important insight into the pricing dynamics of REITs versus other equities.

The outline of this study is as follows. The second section briefly reviews the literature. The third section describes the relevant characteristics of REIT dividend policies and our data set. The section following describes the econometric results, and the final section presents our conclusions.

\section{Background Literature}

The initial finding of Shiller $(1979,1981)$ and LeRoy and Porter $\{1981)$ was that stock prices cannot adequately be explained by the present value of dividends or dividend changes. These results generated much literature and debate. Their techniques assume the structure given in Equation (I)-a

\footnotetext{
${ }^{2}$ Wang, Erickson and Gau $\{1993)$ find that REITs generally pay out more than $95 \%$ of their taxable income as dividends. See also Chapter 8 of Chan, Erickson and Wang (2003).
} 
present value relation with a constant discount rate and stationary returns. However, the conclusions of these "first-generation" models have been criticized on a number of dimensions. ${ }^{3}$

Researchers initially used relations similar to Equation (I) to test for "excess volatility." They (see footnote 1) generally, but not universally, found that these models fit poorly and emphasized the fact that the variance of $P_{t}^{*}$ was significantly higher than the variance of the dividend series. These findings spawned a wide variety of possible economic interpretations, in addition to a broad range of econometric issues. One of the first economic explanations was that the excess volatility is an artifact of the relative smoothness of dividends. ${ }^{4}$ That is, because of market reactions to dividend changes, firms are very reluctant to raise dividends unless they believe the increase is unlikely to be reversed in the short term. Lintner (1956) and subsequent research have documented this fact. As will be noted below, tests of the relation between dividend and price volatility assume a specific dividend process. ${ }^{5}$ If managers rationally anticipate these market reactions ${ }^{6}$ a small change in dividends can have a large impact on future returns. A different strand of literature attempts to explain this apparent lack of fit of dividend pricing models by refining the econometric approaches to account for time-varying volatility and other possible sources of nonstationarity: these are described in the following section. In addition, there is significant evidence that small sample tests are biased toward accepting excess volatility. ${ }^{7}$ Finally, a number of researchers have shown that learning by rational agents plays a role in increasing volatility. ${ }^{8}$

More recently, rather than viewing (1) as a way to gauge market rationality, researchers have looked at this relation as a pricing model with very strong embedded assumptions. In particular, emphasis has been placed on the restriction of a constant discount rate. Rejections of models based on (I) are thus seen as rejections of a particular pricing model. This point is articulated in Cochrane (1991). The second generation tests address these econometric issues. ${ }^{9}$ West (1988a) derives a variance bound test that does not require dividends to be stationary. However, the test assumes that either the dividends or the first difference of dividends are stationary. Thus, it is valid only for nonstationary linear

\footnotetext{
${ }^{3}$ Examples include Flavin (1983). Kleidon (1986a, 1986b) and Marsh and Merton (1986). For further details see Shiller (1989) and Campbell, Lo and MacKinlay (1997).

${ }^{4}$ An example is Kleidon (1986b).

${ }^{5}$ For example, West (1988a) assumes dividends follow an AR(q) process.

${ }^{6}$ See the extensive literature dealing with dividends as a signal of firm quality, for example, Williams (1988) and Lease et al. (2000).

${ }^{7}$ See Flavin (1983) and Kleidon (1986a, 1986b).

${ }^{8}$ See Timmermann (1993). Related work is Spiegel (1998) who shows that in an overlapping generations model, relatively small supply shocks can lead to very large price shocks.

${ }^{9}$ For an exposition of the econometric issues involved, see West (1988b), Cochrane (1991), Gilles and LeRoy (1991) and LeRoy and Steigerwald (1995).
} 
dividend processes. Given the nature of many economic time series, it may be more appropriate to specify a log-linear, rather than a linear, process for dividends to generate stationary dividend growth rates. LeRoy and Parke (1992) develop a variance bound in a log-linear setting for dividends, which is analogous to West's (1988a) bound in a linear setting. Despite these refinements, both articles reject the dividend pricing model using real and simulated data respectively.

Campbell and Shiller (1987, 1988a, 1988b) focus on the present value relation in a vector autoregression (VAR) framework. They note that if the dividend pricing model is valid, and if the optimal predictor of the present value of future dividends is the current price alone, it follows that the present value model implies testable restrictions on the coefficients of a bivariate vector autoregression of stock prices and dividends. Campbell and Shiller derive a log-linear approximation of the present value model. The present value model that results expresses the log price dividend ratio as the present value of expected dividend growth rates. Campbell and Shiller develop a variety of tests tor the equality of the log dividend price ratio and the present value of future dividend growth rates. Again, they reject the dividend pricing model. Campbell and Shiller also compare the standard deviation of the log of the actual dividend price ratio to the standard deviation of the present value of the future expected dividend growth rates. If the present value model is correct, these variables and their .standard deviations must be equal. Campbell and Shiller (1988a) find that the standard deviation of the actual price dividend ratio is roughly twice the theoretical counterpart.

An important critique of the above approaches is that they assume that the process driving dividends is constant over time; see for example, Lehmann (1993). This is especially problematic when the data used are annual and the time periods are rather long. This problem should be less significant in our data since we use quarterly data and the dividend patterns reasonably closely approximate stationarity. ${ }^{10}$

In addition to these econometric issues, the two further criticisms of the dividend pricing results most important to our analysis concern the apparent smoothing of dividends that has been empirically observed since the $1950 \mathrm{~s}^{11}$ and the fact that taking a broader characterization of payoffs than just dividends seems to mitigate the excess volatility. ${ }^{12}$ The former point is merely that inferences from a highly smoothed series would bias the results towards excess volatility. The latter critique is that focusing entirely on dividends omits many other factors relevant to price formation. Since share repurchase has increasingly become a substitute for dividend payments, it should be incorporated into

\footnotetext{
${ }^{10}$ This can be seen in Figure 3 below.

${ }^{11}$ See Fama and Babiak (1968) and Lintner (1956).

${ }^{12}$ See Kleidon (1986a, 1986b). Marsh and Merton (1986) and Ackert and Smith (1993).
} 
the analysis. Ackert and Smith (1993), using West's methodology, show that aggregating share repurchases and other distributions with the dividend payments reverses the earlier rejections of the dividend pricing model.

The net result of the above research is thus somewhat mixed. While it is clear that the assumptions underlying simple dividend pricing models like Equation $\{1$ ) are severe and unlikely to truly capture market realities, the results of Ackert and Smith (1993) suggest that the definition of dividends may be a key reason for the rejections of the dividend pricing models.

In the next section we clarify the unique nature of REIT dividend payout practices. The section following will test this dividend pricing relation on REITs.

\section{Data and REIT Dividend Behavior}

Although the REIT dividend restriction is based on taxable income, most REITs pay out more than the legal lower bound. Due to the relatively large amounts of depreciation and low levels of capital expenditures, the cash flow of a REIT generally exceeds its taxable earnings. Figure 1 shows this. This exhibit is based on the 50 largest REITs (as defined by market capitalization as of August 1999). ${ }^{13}$ The median dividend payout is $111 \%$ of taxable income. Only three REITs paid out the regulated $95 \%$ figure, suggesting that REITs exercise some control over dividend payouts.

The industry tends to use funds from operations (FFO) to measure performance and to establish dividend payouts. ${ }^{14}$ Essentially. FFO is net income, excluding gains and losses from debt restructuring and property sales, adding back depreciation and amortization, and after adjustments for unconsolidated partnerships and joint ventures. ${ }^{15}$ Figure 2 shows the dividend distribution based on FFO for the largest REITs in 1998 . The median REIT payout was $86 \%$ of FFO; $84 \%$ of the REITs paid out between $70 \%$ to $105 \%$ of FFO. Figure 3 gives the average dividend payout as a function of FFO for 1992 to 1997. The data represent the Goldman Sachs REIT universe for this time period. For each quarter, dividend payout has been between $79 \%$ and $90 \%$ of FFO.

\footnotetext{
${ }^{13}$ Data are from the NAREIT website; http://www.nareit.org and Bloomberg. REITs without taxable Income or which ceased to be REITs (usually because of merger) during the year were excluded. This leaves a set of 43 REITs ${ }^{14}$ Another performance metric used by practitioners is funds available for distribution (FAD), although no formal definition of this term has been broadly accepted.

${ }^{15}$ See "NAREIT White Paper on Funds from Operations," March 1995 for details; this paper is available on the NAREIT website http://www.nareit.org.
} 
Figure 1 Dividend payout as a percent of taxable income. This figure gives the 1999 distribution of REIT dividend payout as a percent of taxable income. The data are based on the 50 largest REITs as of August 1999. The data for seven are excluded because of negative taxable income or because they changed from a REIT to another organizational form.

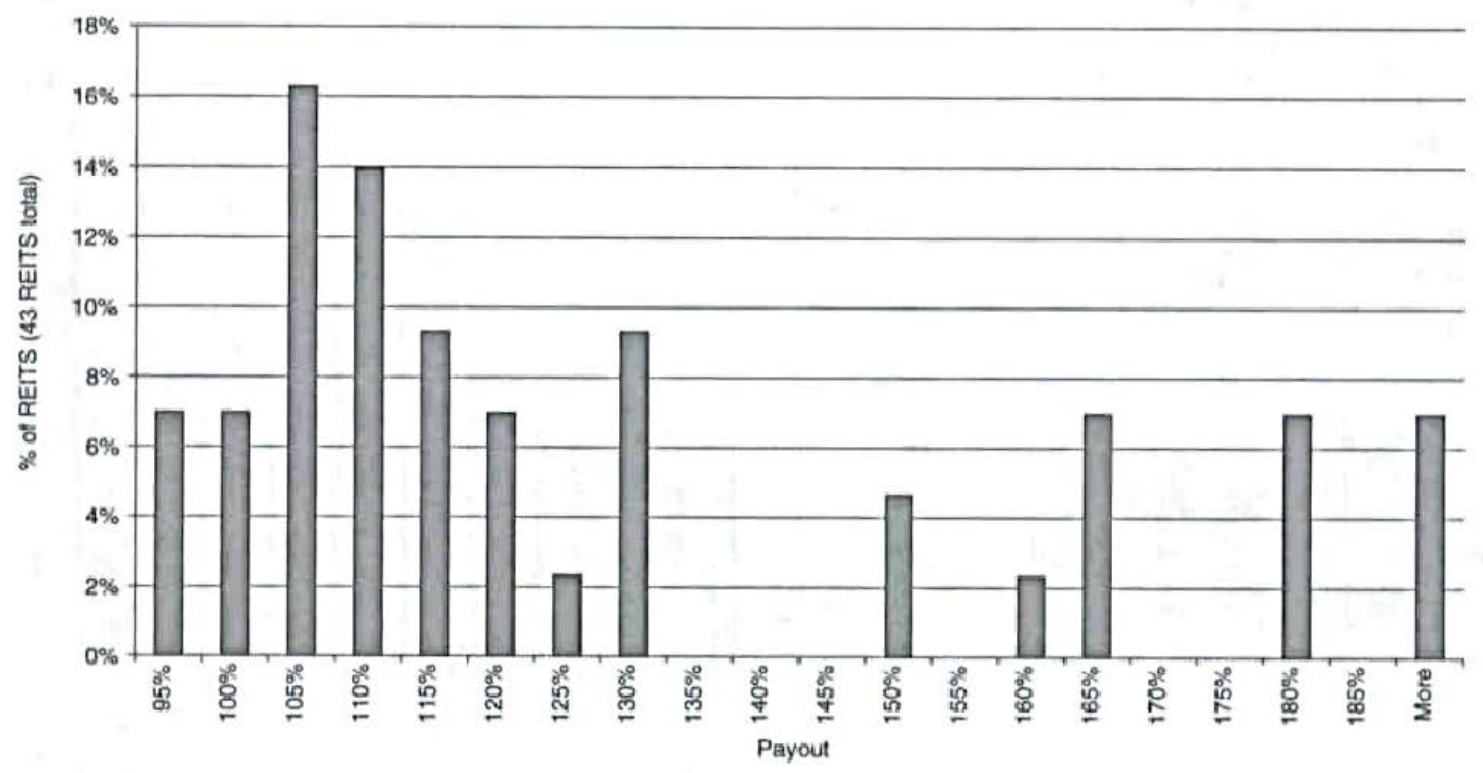

These figures show that, while REITs have a measure of discretion in their dividend payout, ${ }^{16}$ they consistently pay out about $85 \%$ of FFO as dividends. Since these figures show a wide disparity with what is observed for the normal equity, ${ }^{17}$ it is not surprising that the reaction to dividend announcements is different for REITs than for regular equities. This is documented in Wang, Erickson and Gau (1993). They find an abnormal return on dividend increase announcements of $0.66 \%$ for equity REITs and $0.38 \%$ for mortgage REITs. The corresponding figures for dividend decreases are $-1.9 \%$ and $0.11 \%$. While three of these four abnormal returns are significant at the 0.05 level, the market reactions are much less (approximately 40\%) than figures reported for normal equities. ${ }^{18}$

In our analysis, rates of return include capital gains and all ca.sh distributions. Ackert and Smith (1993) suggest that a major problem with tests of the dividend pricing model is that the computed payoffs include only cash dividends. Therefore, our specification of dividends includes all cash and share distributions to shareholders from ordinary dividends, special dividends and mergers. Figure 4 shows the

\footnotetext{
${ }^{16}$ See Bradley, Capozza and Seguin (1998) for discussion of this issue.

${ }^{17}$ For example, the average dividend payout for U.S. corporations over the period 1973 to 2000 is $35.0 \%$ of pretax profits; see www.bea.gov for details.

${ }^{18}$ Amihud and Li (2003) document the diminishing market reaction to the announcement of dividend changes.
} 
distribution of REIT payouts over our sample period. ${ }^{19}$ On average, share repurchases represent 13.2\% of the total. The corresponding figure in Ackert and Smith's study is approximately $50 \% .{ }^{20}$ This suggests that the Ackert and Smith resolution will be less meaningful with our data.

Figure 2 a Dividend payout as a percent of funds from operations (FFO). This figure gives the 1999 distribution of REIT dividend payout as a percent of funds from operations. The data are based on the 50 largest REITs as of August 1999. The data for seven are excluded because of negative taxable income or because they changed from a REIT to another organizational form. The figure shows that the median payout is $86 \%$ of FFO. Eighty-four percent of the REITs paid out between 70 to $105 \%$ of FFO.

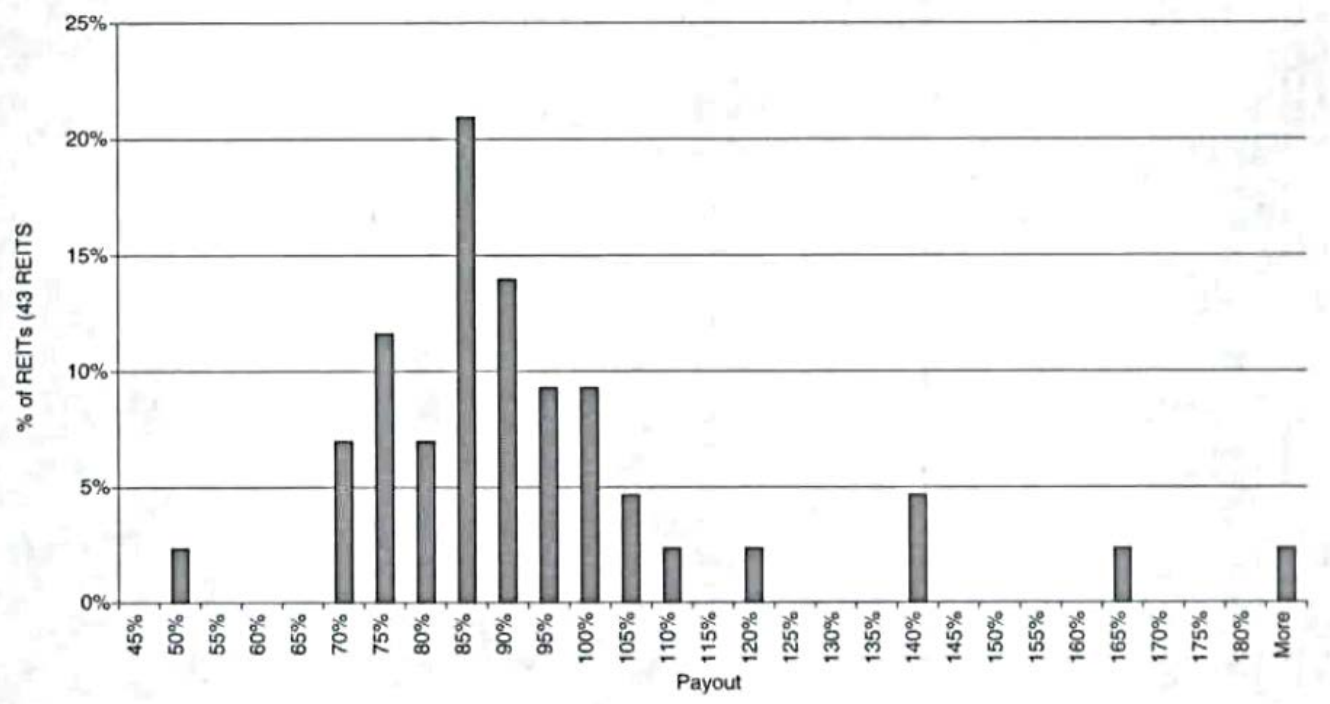

Our empirical tests use a value-weighted, quarterly REIT index based on all available, publicly traded (NYSE, AMEX and Nasdaq) REITs from January 1973 to December 2001. Since REITs began actively trading in the early 1970s, we have a relatively short time span for testing using annual data; using quarterly data mitigates this problem. ${ }^{21}$ Quarterly data are subject to potential biases due lo possible annual patterns in dividend payout: the fact that REITs pay out almost all aftertax profits as dividends reduces this potential bias. ${ }^{22}$ Since the majority of REITs were created in the 1980 s, we have a varying number of REITs in our index, ranging from 7 at its inception to 84 at the end of our time period.

In case of missing returns, we interpolate for the missing period using the end points. ${ }^{23}$ The price index is deflated by the quarterly producer price index, ${ }^{24}$ which is the benchmark used in most

\footnotetext{
${ }^{19}$ This figure uses all REITs with data available on COMPUSTAT.

${ }^{20}$ See their Figure 1.

${ }^{21}$ Shiller (1989) discusses the length of the time series required for testing dividend pricing models.

${ }^{22}$ The first four autocurrelations of the first differenced dividend series are $0.052,-0.314,0.038$ and 0.078 , respectively. Only the second autocorrelation is significant.

${ }^{23}$ Note that this would cause a slight downward bias in our estimates of REIT volatility. However, interpolation is used in less than $0.01 \%$ of the observations.
} 
studies of dividend pricing models. The index construction is similar to the S\&P index, with the divisor being adjusted for the addition of new companies and the delisting of companies. Federal Reserve statistical releases are used to convert the nominal to a real series and for the interest rate used (the annualized yield on AA-rated commercial paper) lo calculate the excess return.

Figure 3 a REIT average dividend to funds from operations payout ratio. This figure plots the average dividend to funds from operations payout ratio for the Goldman Sachs REIT universe of 52 REITs. For each quarter, dividend payout is between $79 \%$ and $90 \%$, with a slight decline over this time period.

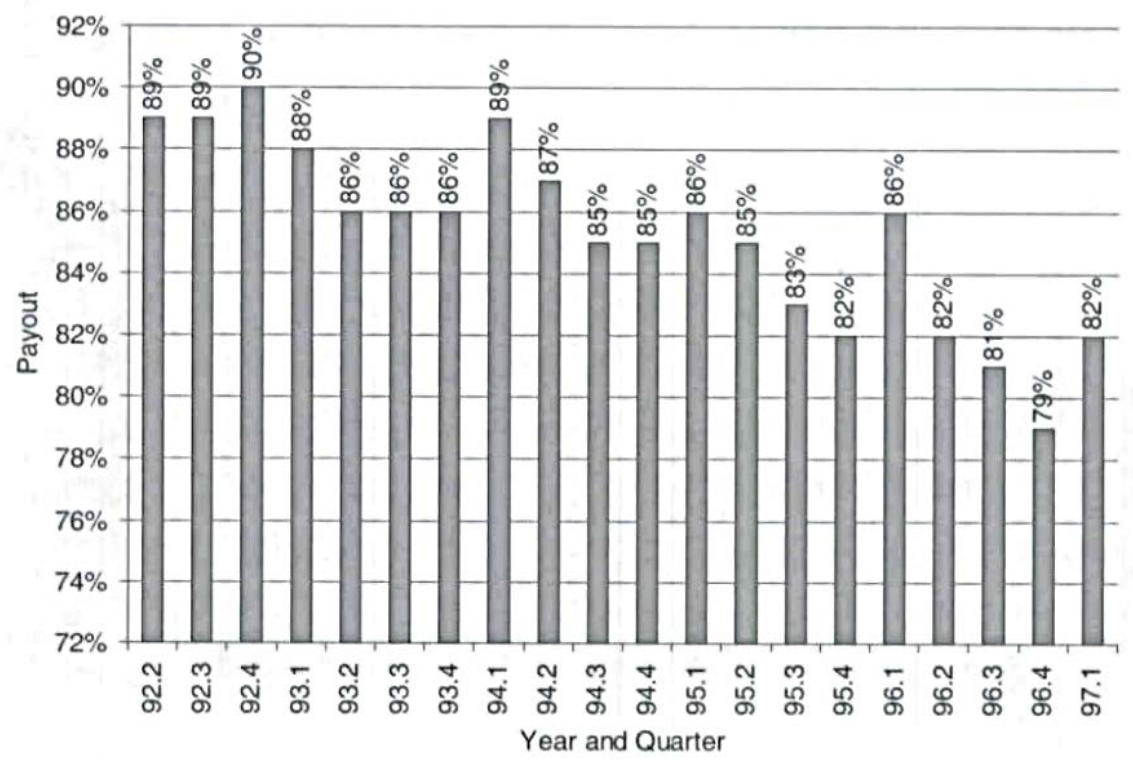

Figure $4 \mathbf{a}$ :Volume of dividends and repurchase for REITs. This diagram gives the relative magnitude of common dividends, preferred dividends and share repurchase for all REITs with data available on Compustat. Over this time period, common dividends average $78.0 \%$ of the total, share repurchase is $13.2 \%$ and preferred dividends are $8.8 \%$.

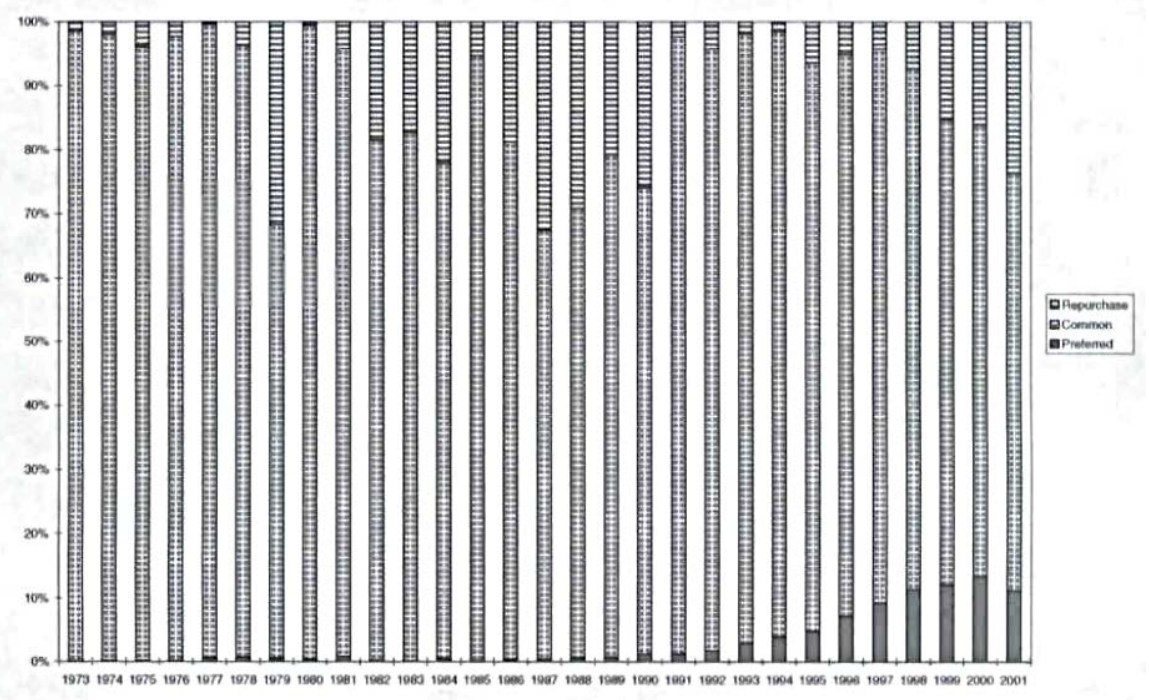

${ }^{24}$ The details of the procedure can be found in Shiller (1981). 


\section{Methodology and Results}

The methodology of West (1988a) and of Campbell and Shiller (1988a) is used to test the dividend pricing model. ${ }^{25}$ We perform West's tests on our REIT index using the deflated price series and the first difference of the dividend series. The key intuition in West's approach is that the variance of the price based on a smaller information set has to be larger that the variance based on a larger information set. The actual market price of any security is based on the market's information set, $l_{t}$, which is clearly larger than the information set, $H_{t}$ generated by any specific set of instrumental variables that could be used. Using the notation of Equation (1), this notion is captured in the inequality

$$
E\left[x_{t H}-P\left(x_{t H} \mid H_{t-1}\right)\right]^{2} \geq E\left[p_{t}+d_{t}-E\left(p_{t}+d_{t} \mid I_{t-1}\right)\right]^{2} .
$$

Here the left-hand side is the innovation in the present value of dividends based on a restricted information set; the right-hand side is the expected innovation in the present value of dividends based on the market's information set. Since the market's information set cannot be directly observed. West uses an instrumental variable approach to estimate the discount model

$$
p_{t}=b\left(p_{t+1}+d_{t+1}\right)+u_{t+1},
$$

using Hansen and Singleton's two-step, two-stage, least squares with lagged dividends as instruments. The left-hand side is

$$
\Delta^{2} d_{t+1}=\mu+\phi_{1} \Delta^{s} d_{t}+\cdots+\phi_{q} \Delta^{s} d_{t-q-1}+v_{t+1} .
$$

Using this structure, and assuming a null hypothesis of no excess volatility. West derives the following inequality (Equation 16 in his paper)

$$
\delta_{1}^{2} \sigma_{v}^{2}-\frac{\sigma_{u}^{2}}{b^{2}} \geq 0
$$

where $\delta$ is a function of $b$ and the $\theta$ vector. The standard errors of the estimates are calculated using analytical derivatives. ${ }^{26}$

The central test is based on Inequality (5), which is displayed in the last row of Table I. The null hypothesis is that the left-hand side of (5) is positive, which it is with our REIT data. This is in direct contrast to our estimation of the model on the S\&P quarterly index over the same time period, 1973 to 2001, as used for the REIT index. Here the negative value, -0.12 , leads to rejection, as in West's original

\footnotetext{
${ }^{25}$ We are grateful to John Campbell for providing us with his Gauss algorithm and to Kenneth West for helpful comments on the implementation of his algorithm.

${ }^{26}$ See West (1988a) for further details.
} 
analysis. ${ }^{27}$ This means that, even with our newer data set (using data from the 1980s and 1990s) and switching to quarterly data, the original insight of West, that is, the rejection of the dividend pricing relation on equity indexes, continues to be valid. Conversely, when applied to our REIT index, the model cannot be rejected. We next test if this conclusion is robust by using a different technology.

Campbell and Shiller (1988a), starting with the present value model, taking logs and using a Taylor's series approximation, derive what they term the dividend ratio model, or the Dynamic Gordon Model:

$$
\delta_{t}=E_{t} \sum_{j=0}^{\infty} \rho^{j}\left(r_{t-j}-\Delta d_{t-j}\right)+C,
$$

where $\delta_{t}$ is the log of the ratio of dividends to price in period $t ; r_{t-j}$ is the ratio of the price to the sum of the price and dividend in period t; $\rho$ is the ex post, observed discount rate and $\Delta d_{t+j}$ is the log dividend growth rate.

Table 1 a REIT tests using West's methodology.

\begin{tabular}{lrl}
\hline \hline Parameter & \multicolumn{1}{l}{ Value } & Standard Error \\
\hline Panel A: REIT Index & & \\
\hline$b$ & 0.9550 & 0.0159 \\
$\mu$ & 0.0492 & 0.0249 \\
$\varphi_{1}$ & -0.7964 & 0.1088 \\
$\varphi_{2}$ & -0.5857 & 0.1519 \\
$\varphi_{3}$ & -0.3880 & 0.1899 \\
$\varphi_{4}$ & -0.1575 & 0.0957 \\
$\sigma_{u}^{2}$ & 4.2181 & 1.3708 \\
$\sigma_{v}^{2}$ & 0.1195 & 0.0363 \\
Equation (5) & 2.8945 & 1.43 \\
\hline Panel B: Quarterly S\&P 500 Index & & \\
\hline$b$ & & 0.0159 \\
$\mu$ & 0.9808 & 0.0249 \\
$\varphi_{1}$ & 0.0002 & 0.1088 \\
$\varphi_{2}$ & -0.7441 & 0.1519 \\
$\varphi_{3}$ & -0.2359 & 0.1899 \\
$\varphi_{4}$ & -0.1067 & 0.0957 \\
$\sigma_{u}^{2}$ & 0.1289 & 1.3708 \\
$\sigma_{v}^{2}$ & 0.0034 & 0.0363 \\
Equation (5) & 0.0000 & 0.0369 \\
\hline
\end{tabular}

This table tests the West (1988a) dividend pricing model on our REIT index (Panel A) and on the S\&P 500 index (Panel B). The data are quarterly from the beginning of 1973 to the end of 2001 with the data series adjusted for inflation. The null hypothesis is rejected if the parameter in the last row, Equation (5), is significantly negative. The coefficients are from the estimation of Equation (4) in the text.

\footnotetext{
${ }^{27}$ This value is 3.1 times its standard error.
} 
In Equation (6), the constant, $C$, describes how this observable discount rate is related to the actual unobservable discount rate used to value stocks. A key assumption is that the unobservable discount rate differs from the observed only by a constant. The above model can be applied both to real and nominal prices and dividend series since only the difference between the ex post discount rate and the log of the dividend growth rate is important for the analysis. It accounts for time-varying discount rates by assuming that the discount rate is a constant spread over the commercial paper yield.

Campbell and Shiller's (1988a) method compares movements of the dividend price ratio with the movements implied by $u$ VAR model. Let.$x_{t}$ be the vector $\left[\delta_{t}, r_{t-1}-\Delta d_{t-1}\right]$. The information set $H_{t}$ is the history of all past observations of the $x_{t}$ vector. Here the means from the data are removed, since they are not restricted by the model. The dividend growth rates are lagged by one period to ensure that they are known to market participants at the beginning of the period. It is assumed that the linear process for $x$, can be written as a VAR process with $\rho$ lags, that is,

$$
x_{t}=\sum_{i=1}^{p} C_{i} x_{t-i}+u_{t},
$$

where $C_{i}$ for $i=1, \ldots, p$ is a $2 \times 2$ matrix. We can convert Equation (7) into a first-order autoregression with a tractable form for the conditional expectation. We define the vector $z_{t}$, which includes $2 p$ elements rather than 2 elements: $\delta_{t}$ and $r_{t}-\Delta d_{t}$ and $(p-l)$ lags of each. The vector $z_{t}$ then follows a first-order VAR process, where only the rows corresponding to $\delta_{t}$ and $\Delta \mathrm{d}_{\mathrm{t} 1}$ are stochastic. We now have

$$
\delta_{t}=E\left[\sum_{j=0}^{\infty} \rho^{j}\left(r_{t+j}-\Delta d_{t+j}\right) \mid H_{t}\right] .
$$

Define $e_{1}$ such that $e_{1}{ }^{\prime} z_{t} \equiv \delta_{t}$ and $e_{2}$ such that $e_{2}{ }^{\prime} z_{t} \equiv r_{\mathrm{t}-1}-\Delta \mathrm{d}_{\mathrm{t}-1}$. These vectors thus select the elements $\delta_{\mathrm{t}}$ and $r_{\mathrm{t}-1}-\Delta \mathrm{d}_{\mathrm{t}-1}$ from the vector $Z_{t}$. To derive the restriction of the log-linear model described above, take expectations of both sides of Equation (8) conditional on the information set $H_{t}$. Then we have (ignoring constant terms)

$$
z_{t}=A z_{t-1}+v_{t}
$$

Now,

$$
\delta_{t}=e_{1} z_{t}=E\left[\sum_{j=0}^{\infty} \rho^{j} e_{2}^{\prime} A^{j+1} z_{t}\right] .
$$

Since Equation (10) holds for all realizations of $Z_{t}$ we have 


$$
e_{1}^{\prime}=\sum_{j=0}^{\infty} \rho^{j} e_{2}^{\prime} A^{j+1}=e_{2}^{\prime} A(I-\rho A)^{-1} .
$$

Equation (11) tests that the stock price equals its best VAR estimate. It defines a set of $2 p$ nonlinear restrictions on the VAR coefficients, which can be tested using a nonlinear Wald test. We write the vector of VAR coefficients as $r$, the estimated variance-covariance matrix as $\Theta$ and the vector of deviations from the model as $\lambda$ (equal to $\left.e_{1}{ }^{\prime}-e_{2}{ }^{\prime} A(I-\rho A)^{-1}\right)$. Then the Wald statistic is

$$
\lambda^{\prime}\left[\frac{\partial I^{\prime}}{\partial g} \Theta \frac{\partial I}{\partial g}\right] \lambda .
$$

Under the null hypothesis, the Wald statistic is distributed as a $x^{2}$ with degrees of freedom equal to the number of restrictions (the number of elements of $\lambda$ ). The derivatives of $\lambda$ with respect to the parameters are calculated numerically.

The results of these tests are displayed in Table 2. As in Table 1, we display the results of the Campbell and Shiller methodology on quarterly S\&P 500 returns over the 1973 to 2001 period for comparison. From Panel A, we see that for each of the lags used (two through five), the dividend ratio model is not rejected for REITs. The $p$-values all exceed 0.19 . Thus, the dividend pricing model appears to do a good job of predicting the future dividend price ratio. Conversely, in Panel $B$, the results show that the dividend pricing model is strongly rejected al each of the lags used when tested on S\&P 500 quarterly data. Furthermore, the ratio of standard deviations of the predicted and actual dividend price ratios is higher for the REIT index (averaging 0.60) than for the S\&P 500 index (averaging 0.40). These results confirm the earlier analysis using West's approach. Thus, our conclusion that the present value/dividend pricing relation is an adequate explanation of REIT returns is not dependent upon the choice of methodology. As well, the dividend pricing model, now applied to more recent and quarterly (rather than annual) S\&P 500 data, is strongly rejected using both techniques. This suggests that the findings of West's (1988a) and Campbell and Shiller's (1988a) techniques are robust to time period and data frequency.

The analysis of Bradley, Capozza and Seguin (1998) provides some insight into our findings. They show that anticipated cash-flow volatility is an important determinant of a REIT's dividend policy. More specifically, they find that the dividend payout ratio is inversely related to the level of expected uncertainty in future REIT cash flows. This evidence, combined with the observations on REIT dividend payouts presented earlier in this study, suggests that the connection between REIT dividend behavior and real cash flows (and thus firm value) is much closer than for other equities, and hence, dividend 
pricing models ought to provide a better explanation for REIT returns than for other equities or equity indexes.

Table 2 a REIT tests using Campbell and Shiller's methodology.

\begin{tabular}{|c|c|c|c|c|}
\hline Number of Lags & $\chi^{2}$ Statistic & $p$-value & $\begin{array}{l}\text { Ratio of Standard } \\
\text { Deviations of } \\
\text { Predicted and Actual } \\
\text { Dividend-Price Ratios }\end{array}$ & Standard Error \\
\hline \multicolumn{5}{|c|}{ Panel A: REIT index } \\
\hline 2 & 3.37 & 0.4986 & 0.5970 & 0.2263 \\
\hline 3 & 7.54 & 0.2736 & 0.7575 & 0.3358 \\
\hline 4 & 7.76 & 0.4576 & 0.4832 & 0.4067 \\
\hline 5 & 13.57 & 0.1938 & 0.5485 & 0.5514 \\
\hline \multicolumn{5}{|c|}{ Panel B: S\&P Index } \\
\hline 2 & 25.78 & .000 & 0.2578 & 0.3233 \\
\hline 3 & 44.16 & .000 & 0.5113 & 0.4560 \\
\hline 4 & 51.49 & .000 & 0.4332 & 0.3592 \\
\hline 5 & 73.00 & .000 & 0.3900 & 0.3549 \\
\hline
\end{tabular}

This table tests the Campbell-Shiller dividend pricing model on our REIT index (Panel A) and on the S\&P 500 index (Panel B). The data are quarterly from the beginning of 1973 to the end of 2001 with the data series adjusted for inflation. The $\chi^{2}$ statistic (for the nonlinear Wald test) tests the null hypothesis that the dividend pricing model holds. The null hypothesis is rejected if the $\chi^{2}$ value is sufficiently high.

\section{Conclusions}

In this study we use the methodology of West (1988a) and Campbell and Shiller (1988a) to test the viability of dividend pricing models. We focus on a restricted class of equities, REITs, which have a much stronger link between current dividends and future cash flows. Our research develops some strong and perhaps surprising facts. Using both the West methodology and the Campbell-Shiller methodology, in sharp contrast to the authors' findings and to related research, we find that we cannot reject the basic dividend pricing relation. This rejection is not based on a differing data set used or on the switch to quarterly from annual data, since we obtain results comparable to West's and Campbell and Shiller's when we look at quarterly S\&P 500 data over a time period matching our REIT sample period.

While our results complement those of Ackert and Smith (1993), our data contain a much less significant amount of share repurchase, so that our approach from theirs. Our research shows that, for our REIT population, these models cannot be rejected. This suggests that, for REITs, the current dividend 
payout is a credible signal of the future prospects of the firm, and thus the present value models should fit better than for other equities or equity indexes.

\section{References}

Ackert, L. and B. Smith, 1993. Stock Price Volatility. Ordinary Dividends and Other Cash Flows to Shareholders. Journal of Finance 48(4): 1147-1160.

Amihud. Y. and K. Li, 2003. The Declining Information Content of Dividend Announcements and the Effects of Institutional Holdings. Working paper. Stem School of Business: New York.

Bradley. M., D.R. Capozza and P.J. Seguin, 1998. Dividend Policy and Cash-Flow Uncertainty. Real Estate Economics 26(4): 555-580.

Campbell, J.Y., A. Lo and A.C. MacKinlay, 1997. The Econometrics of Financial Markets. Princeton University Press: Princeton. N.J.

Campbell, J.Y. and R.J. Shiller, 1987. Cointegration and Tests of Present Value Models. Journal of Political Economy 95: 1062-1088.

, 1988a. The Dividend Price Ratio and Expectations of Future Dividends and Discount Factors. Review of Financial Studies 1(3): 195-228.

—, 1988b. Stock Prices, Earnings and Expected Dividends. Journal of Finance 43(3): 661-676.

Chan. S.H., J. Erickson and K. Wang, 2003. Real Estate Investment Trusts: Structure, Performance, and Investment Opportunities. Oxford University Press: New York.

Cochrane, J. 1991. Volatility Tests and Efficient Markets: A Review Essay. Journal of Monetary Economics 27: $463-485$.

Fama, E. and H. Babiak, 1968. Dividend Policy: An Empirical Analysis. Journal of American Statistical Association 63: 1132-1161.

Flavin, M. 1983. Excess Volatility in Financial Markets: A Reassessment of the Empirical Evidence. Journal of Political Economy 91: 929-956.

Gilles, C. and S. LeRoy. 1991. Econometric Aspects of the Variance-Bounds Tests: A Survey. Review of Financial Studies 4(4): 753-791.

Kleidon, A. 1986a. Bias in Small Sample Tests of Stock Price Rationality. Journal of Business 59: 237-261.

1986b. Variance Bounds Tests and Stock Price Valuation Models. Journal of Political Economy 94:953-1001

Lease, R.C. K. John. A. Kalay, U. Loewenstein and O.H. Sarig. 2000. Dividend Policy: Its Impact on Firm Value. Harvard University Press: Cambridge. MA. 
Lehmann. B. 1993. Earnings, Dividend Policy and Present Value Relations: Building Blocks of Dividend Policy Invariant Cash Flows. Review of Quantitative Finance and Accounting 3: 263-282.

LeRoy. S.F. and W.R. Parke, 1992. Stock Price Volatility: Tests Based on the Geometric Random Walk. American Economic Review 82: 981-992.

LeRoy. S.F. and R. Porter, 1981. The Present-value Relation: Tests Based on Implied Variance Bounds. Econometrica 49: 555-574.

LeRoy, S.F. and D.G. Steigerwald, 1995. Volatility. R.A. Jarrow. V. Maksimovic and W.T. Ziem, editors. Handbooks in Operations Research and Management Science. Vol. 9. Elsevier: Amsterdam.

Lintner, J. 1956. Distribution of Incomes of Corporations among Dividends. Retained Earnings and Taxes. American Economic Review 46: 97-113.

Marsh, T. and R. Merton. 1986. Dividend Variability and Variance Bounds Tests for the Rationality of Stock Market Prices. American Economic Review 76: 483-498.

Shiller. R.J. 1979. The Volatility of Long Term Interest Rates and Expectations Models of the Term Structure. Journal of Political Economy 87: 1190-1219.

1981. Do Stock Prices Move Too Much to Be Justified by Subsequent Changes in Dividends? American Economic Review 71: 421-436. 1989. Market Volatility. MIT Press: Cambridge. MA.

Spiegel. M. 1998. Stock Price Volatility in a Multiple Security Overlapping Generations Model. Review of Financial Studies 11(2): 419-447.

Timmermann, A.G. 1993, How Learning in Financial Markets Generates Excess Volatility and Predictability in Stock Prices. Quarterly Journal of Economics 108: 1135-1145.

Wang, K., J. Erickson and G.W. Gau. 1993. Dividend Policies and Dividend Announcement Effects for Real Estate investment Trusts. AREUEA Journal 2I\{2): 185-201.

West, K.D. 1988a. Dividend Innovations and Stock Price Volatility. Econometrica 56: 37-61. , 1988b. Bubbles. Fads and Stock Price Volatility Tests: A Partial Evaluation. Journal of Finance 43: 636-656.

Williams, Joseph. 1988. Efficient Signaling with Dividends. Investment and Stock Repurchases. Journal of Finance 43: 737-747. 